\title{
UNRAVELING THE ROLE OF COGNITION IN THE INTERNATIONALIZATION PROCESS
}

\author{
Flávio Bressan ${ }^{1}$, Cristiano Morini, Edmundo Inácio Júnior, Elisabet Garcia Fuentes ${ }^{\Omega}$ \\ Universidade Estadual de Campinas - Unicamp, Campinas, São Paulo (Brasil) \\ $\Omega$ Universitat Politècnica de Catalunya, Barcelona (Espanha)
}

\section{ARTICLE DETAILS}

\section{Article history}

Received: 11 December 2018

Accepted: 20 January 2020

Available online May: 01 th 2020

Double Blind Review System

Scientific Editor

Ilan Avrichir

Key words

Ambidexterity

Mental Model

Internationalization

\begin{abstract}
Objective: The aim of this paper is to verify the effects of triggering stimuli on internationalization and whether, according to the target population, ambidexterity and mental models (MM) increase the predisposition to exports, as well as whether the country of origin causes differences in terms of cognition.

Method: Data collection consisted of applying a questionnaire to a sample of 285 students from Business Administration programs in Brazil and Spain. ANOVA Welsh was used to verify the heterogeneity of variations, the Kolmogorov-Smirnov and Shapiro-Wilk tests were used to assess normality, and nonparametric KruskalWallis tests were used to verify the results of the previous tests.

Main outcomes: The results showed that the strategic MM facilitates internationalization. In the sample studied, it was possible to verify that Brazilians show an operational tendency, with decisions based on logic and an improvised lifestyle, which denotes lower possibility of engaging in internationalization. This differs from what was found in the Spanish sample, which showed tendency to a strategic approach, denoting greater possibility of engagement in an internationalization process. These results may also be used to improve internationalization stimulus programs, considering cognitive aspects.

Relevance: There is a low number of references relating the subject of ambidexterity to the internationalization process. This study is relevant for proposing the creation of indexes to obtain data on the MM and ambidexterity regarding the identification of personal motivation factors influencing the entrepreneur's insertion in international markets.

Theoretical/methodological contributions: Proposition of a formula for standardizing and rescaling the instruments' value, as the differences between scales may contribute to the inclusion of a hidden dimension of the internationalization process: the analysis of cognition.
\end{abstract}

\section{Introduction}

Internationalization efforts have led many countries to create incentive programs designed to engage companies in the access to and penetration of international markets (Engelman \& Fracasso, 2013), receiving attention from government agencies (Acedo \& Galán, 2011). However, the effectiveness of these programs is questionable, as they are not always based on an adequate understanding of the factors and reasons leading companies to enter and compete in foreign markets (Leonidou, Katsikeas, Palihawadana \& Spyropoulou, 2007; Acedo \& Galán, 2011; Khauaja \& Toledo, 2012). In this direction, Acedo and Galán (2011) identified that the perception of opportunities to export and the proactivity of decision-makers (Kiss, Williams \& Houghton, 2013) are factors affecting this disposition toward internationalization. Studies examining the influence of these stimuli did not provide a basis for improving the understanding of this phenomenon, and indicate the need for further studies, both conceptual and empirical, to identify the factors motivating the insertion in international markets (Leonidou et al., 2007).

In addition to the continuous need to contribute to this clarification, Zahra, Newey \& Li (2014) point to the perception of opportunity as an important factor, relating it to the issue of exploitation of opportunity (Keller \& Weibler, 2012), as well as the willingness to deal with the uncertainty of results (Kiss, Williams \&

\footnotetext{
${ }^{1}$ Contato do autor - Email: bremat@terra.com.br
} 
Houghton, 2013), which on the one hand, is associated with ambidexterity and the preference for exploration or exploitation (Keller \& Wibler, 2012; Vahlne \& Jonsson, 2017), and on the other, with the connection between this issue and the entrepreneur's cognition (Feuerstein, 2015).

Cognition has been approached from the perspective of mental models (MM), understood as the pattern of mental work (Bressan, 2018) or as constant and characteristic neurocognitive patterns of perception, processing and use of the information collected (Jung, 2016; Bressan \& Toledo, 2013; Spagnol, Campos, Bressan \& Li, 2015), which can help understand the impact of stimuli and programs on the decisions of entrepreneurs.

To obtain this understanding, this study aims to analyze, as main objective, ambidexterity and the mental models of those involved, with regard to the triggering stimuli influencing the disposition toward internationalization. As a secondary objective, it aims to verify whether the respondents' country of origin indicates differences in this disposition. For this, a survey was carried out based on the propositions of ambidexterity (Keller \& Weibler, 2012) and those of the mental models (Bressan, 2018), including students with similar academic profile and from business schools that offer basic training in entrepreneurship, and who thus have some familiarity with the theme. This choice is justified by the fact that there are numerous studies on students' willingness to become entrepreneurs and considering that higher education aims to establish a platform of relevant knowledge that will help students acquire the necessary skills in their careers (Modak, Patel, Pal, Das \& Nain, 2018; Oliver \& Jorre de St Jorre, 2018).

Understanding the effects of triggering stimuli and how they relate to personal characteristics is an issue that is rarely addressed in the literature, both by academic research - insofar as those seeking to propose a methodology to address this issue - and by agencies in charge of creating programs to stimulate internationalization, despite the fact that the results of this study indicate that these programs' effectiveness may be increased in the long run by better adapting to the preferences and characteristics of entrepreneurs, which may lead to the development of more favorable attitudes on their part toward operations in foreign markets.

The next section provides a review of the literature on ambidexterity and mental models as a substrate to investigate the impact of triggering stimuli on internationalization decisions. The methodology used is then presented, followed by the results, the main findings, the study limitations, and suggestions for future research.

\section{Managerial ambidexterity: exploration and exploitation}

The literature presents two decision models: exploration and exploitation (March, 1991; Birkinshaw \& Gupta, 2013; Keller \& Weibler, 2014). Ambidexterity as a theme is well articulated in the literature on business and management (Keller \& Weibler, 2014), but not in relation to the internationalization process. Exploration decisions can be characterized by the search for new and different options, based on innovation, helping anticipate market changes (March, 1991; Keller \& Weibler, 2014) and making it possible to acquire knowledge and change the company's limits, leading it to explore new skills (Bandeira-de-Mello, Fleury, Aveline \& Gama, 2016).

On the other hand, exploitation decisions are based on the development, efficiency, selection and optimization of resources and skills (March, 1991) to expand the company's product-market domain (Keller \& Weibler, 2014) and maintain its continuity and stability. Exploitation-focused companies/entrepreneurs feel more comfortable with stable markets and technologies (Raisch, Birkinshaw, Probst \& Tushman, 2009). However, a strong focus on exploitation can generate organizational myopia, keeping the company fixated on unsettled markets and resulting in implications associated with a single product market.

The concept of managerial ambidexterity refers to the alternation between the two strategic models (March, 1991), since the adoption of an ambidextrous strategy guarantees sufficient exploitation to ensure the company's current and future viability to allocate resources that are necessary for exploration (Lee, 2015; Vahlne \& Jonsson, 2017). However, exploration and exploitation are two very different logical processes, with many points of conflict (Laureiro-Martínez, Brusoni, Canessa \& Zollo, 2015), because, at the business level, they may be arranged in orthogonal patterns, and not in a gradient (Keller \& Weibler, 2014; Laureiro-Martínez et al., 2015). 
Thus, the preference for one of them may underlie the reactions to internationalization stimuli. The comparison between the definition of proactive and reactive stimuli and of exploration and exploitation (Chart 1) sheds light on the relationship between the higher probability that the adoption of the exploration strategy would lead to a more significant reaction to the proactive stimuli, and that the adoption of the exploitation strategy would lead to a preference for responding to reactive stimuli.

Chart 1. Comparison between the definition of stimuli and ambidexterity

\begin{tabular}{|l|l|}
\hline Internationalization Stimuli & Ambidexterity \\
\hline $\begin{array}{l}\text { Proactive: associated with the deliberate } \\
\text { search for internationalization opportunities. }\end{array}$ & $\begin{array}{l}\text { Exploration: includes aspects such as research, risk- } \\
\text { taking, experimentation, playing, flexibility, discovery } \\
\text { and innovation. }\end{array}$ \\
$\begin{array}{l}\text { Reactive: associated with a more passive } \\
\begin{array}{l}\text { attitude, wherein the activity of } \\
\text { internationalization is a response to changing } \\
\text { circumstances. }\end{array}\end{array}$ & $\begin{array}{l}\text { Exploitation: includes refinement, selection, } \\
\text { production, efficiency, implementation and execution. }\end{array}$ \\
\hline
\end{tabular}

Source: prepared by the authors.

The preference for exploration or exploitation and the preferential reaction to proactive and reactive stimuli may be related to the psychological variables conditioning strategic choices. They may be associated with the different neurocognitive modes of functioning (Bressan, Spagnol \& Min, 2015; Spagnol et al., 2015; Zahra, Korri \& Yu, 2005), which is consistent with the proposition of the $\mathrm{MMs}$ (Bressan, 2018), used to understand possible differences in the reactions to internationalization stimuli. The next section deals with mental models.

\section{Mental Models (MM)}

Individuals, in addition to demographic differences, have differences that impact their behavior and decisions, such as mental models (MM). From a cognitive perspective, these have been defined as the psychological representation of real, hypothetical and imaginary situations, and result from perception, imagination and understanding (Daniel \& Daniel, 2018). Cognitive structures allow describing, explaining and predicting the purpose, form, function and state of a system, and make it possible to interpret meanings in organizational life. However, there are still many demands regarding their extension to problem solving, decision making, and strategic thinking (Carrington, Combe, \& Mumford, 2019).

As a result, based on Jung's study (2016) and the results of a study on neuro-functional functioning (Spagnol et al., 2015), it was decided to define MM as the standard mode of a person's neurocognitive functioning (Bressan, 2018 ). MMs can be inferred from psychological types (Routamaa, Brandt \& UusiKakkuri, 2016) and from temperaments (Keirsey \& Bates, 1978; Silva, 1992; Neal \& Neal, 2009; Bachert, Wechsler \& Machado, 2016). In their definition, three factors are investigated: perception, decision-making modes, and lifestyle. Considering these three factors, MMs offer a valid and useful way to deal with the challenges of the business environment (Magzan, 2012), to deal with strategic choices (Zahra, Korri, \& Yu, 2005), and to deal with different patterns of stimulus towards entrepreneurship (Bressan \& Toledo, 2013) and towards internationalization.

\subsection{Perception}

Perception is an irrational mental process (Jung, 2016) whereby one collects, selects, organizes, interprets and represents the information received from different stimuli in the environment, through which a person appropriates things, people, occurrences, and ideas (Keirsey \& Bates, 1978; Briggs \& Myers, 1995; Tieger \& Barron-Tieger, 2014; Routamaa, Brandt \& Uusi-Kakkuri, 2016).

There are two modes of perception: concrete and global (Jung, 2016). The concrete mode occurs through the sensory organs; its focus is on the concrete world and on tangible reality, leading people to develop greater confidence in experiences. Global perception is characterized as the collection of abstract and conceptual data. It is an indirect type of perception, usually unconscious, reached without the intervention of sensory organs. It allows people to 
take leaps from the past or present to future possibilities, shedding light on complex connections between various phenomena (Keirsey \& Bates, 1978; Silva, 1992; Briggs \& Myers, 1995; Tieger \& BaronTieger, 1998; Pearman et al., 2006; Luiz, 2011).

\subsection{Decision-Making Mode}

Decision-making is a rational process involving the evaluation of perceived information (Jung, 2016). It is classified into logical mode and value-based mode (Pearman et al., 2006; Myers \& Myers, 2010; Ahmed, Hasnain \& Venkatesan, 2012). The logical mode corresponds to the use of logic as a basis for decision making, with establishment of a logical and conceptual connection between groups of perceived facts, leading to impersonal judgments and assessments and to the use of validity and rationality as judgment criteria. The value-based mode denotes a preference for making judgments based on the value, usefulness and importance of things for people, leading to compassion, the pursuit of empathy, and a desire for harmony in the social environment (Keirsey \& Bates, 1978; Silva, 1992;
Routamaa, Brandt \& Uusi-Kakkuri, 2016; Bressan, 2018).

\subsection{Lifestyle}

It corresponds to the interaction with the outside world and to the preferred way of leading one's life. There are two styles: planned and improvised. The planned style indicates a preference for living according to the established standards, guided by customs and stability. The improvised style indicates a preference for living according to current situations, with ease of adjustment to accidents and unexpected events, or in other words, a preference for a more spontaneous life, with ease of adaptation to changing circumstances (Myers \& Briggs, 1995; Keirsey \& Bates, 1978; Felder, Felder \& Dietz, 2002; Pearman et al., 2006; Harrington \& Loffredo, 2010).

This shows there are differences in the ways in which subjects perceive the environment and make decisions. Based on these studies, Bressan (2018) proposed two mental models: The Strategic Mental Model (SMM) and the Operational Mental Model (OMM) (Chart 2).

Chart 2. Synthetic description of the mental models

\begin{tabular}{|c|c|}
\hline MENTAL MODELS & TYPE \\
\hline \multirow{2}{*}{$\begin{array}{l}\text { Operational mental model (OMM): is characterized } \\
\text { by a focus on operation and on the search for precision, } \\
\text { reliability, efficiency, prudence, discipline and } \\
\text { compliance, showing preference for the creation of } \\
\text { plans and drawing satisfaction from their fulfillment. Is } \\
\text { quick to make decisions and, once a decision is made, } \\
\text { it no longer worries him/her. Rarely challenges the } \\
\text { rules, norms and policies, unless with the strong and } \\
\text { explicit support of his/her superiors. }\end{array}$} & $\begin{array}{l}\text { Implementing OMM: prefers it when things have been } \\
\text { decided, in an orderly and well-planned manner; likes to } \\
\text { make plans and carry them out; is guided by } \\
\text { traditionalism, stabilization and consolidation, working } \\
\text { with a sense of responsibility, loyalty and assiduity. } \\
\text { Contribution: timely production. }\end{array}$ \\
\hline & $\begin{array}{l}\text { Pragmatic OMM: uses what has been perceived in an } \\
\text { improvised way. Problem solver, dealer, firefighter, } \\
\text { disdains planning and favors the present moment. } \\
\text { Contribution: dealing effectively and quickly with the } \\
\text { unusual and the unexpected. }\end{array}$ \\
\hline \multirow{2}{*}{$\begin{array}{l}\text { Strategic mental model (SMM): low adherence to } \\
\text { standards; capable of an innovative approach to } \\
\text { problems. Likes identifying and finding solutions to } \\
\text { complex problems. Focused on future possibilities. Is a } \\
\text { visionary. Takes control in situations with low } \\
\text { structure. Self-confident in his/her propositions and } \\
\text { ideas. Applies him/herself to transform or create new } \\
\text { systems. Next step: use of information in decision } \\
\text { making based on logics and rationality - Strategizing - } \\
\text { or on values - Energizing. }\end{array}$} & $\begin{array}{l}\text { Strategizing SMM: tends to make decisions based on } \\
\text { objective and logical analyses, and in an impersonal way. } \\
\text { As a visionary, architect of systems and consultant, he/she } \\
\text { works with creativity and logic. Contribution: strategies } \\
\text { and analyses. }\end{array}$ \\
\hline & $\begin{array}{l}\text { Energizing SMM: tends to decide based on values and } \\
\text { considering people's possibilities, interests and desires. Is } \\
\text { a catalyzer and communicative. Contribution: something } \\
\text { personal or special insight into possibilities. }\end{array}$ \\
\hline
\end{tabular}

Source: prepared based on Keirsey and Bates (1984), Kroeger and Thuessen (1992) and Silva (1992). 
MMs can also work in different ways depending on what happens after perception. The OMM will use information perceived in life either in a planned way - resulting in the "implementing" mental model -, or in an improvised way, resulting in the "pragmatic" model. In the case of the SMM, the next step after perception will be using the information to make decisions, either logically or rationally - resulting in the "strategizing" mental model; or based on values - resulting in the "energizing" mental model (Figure 1).

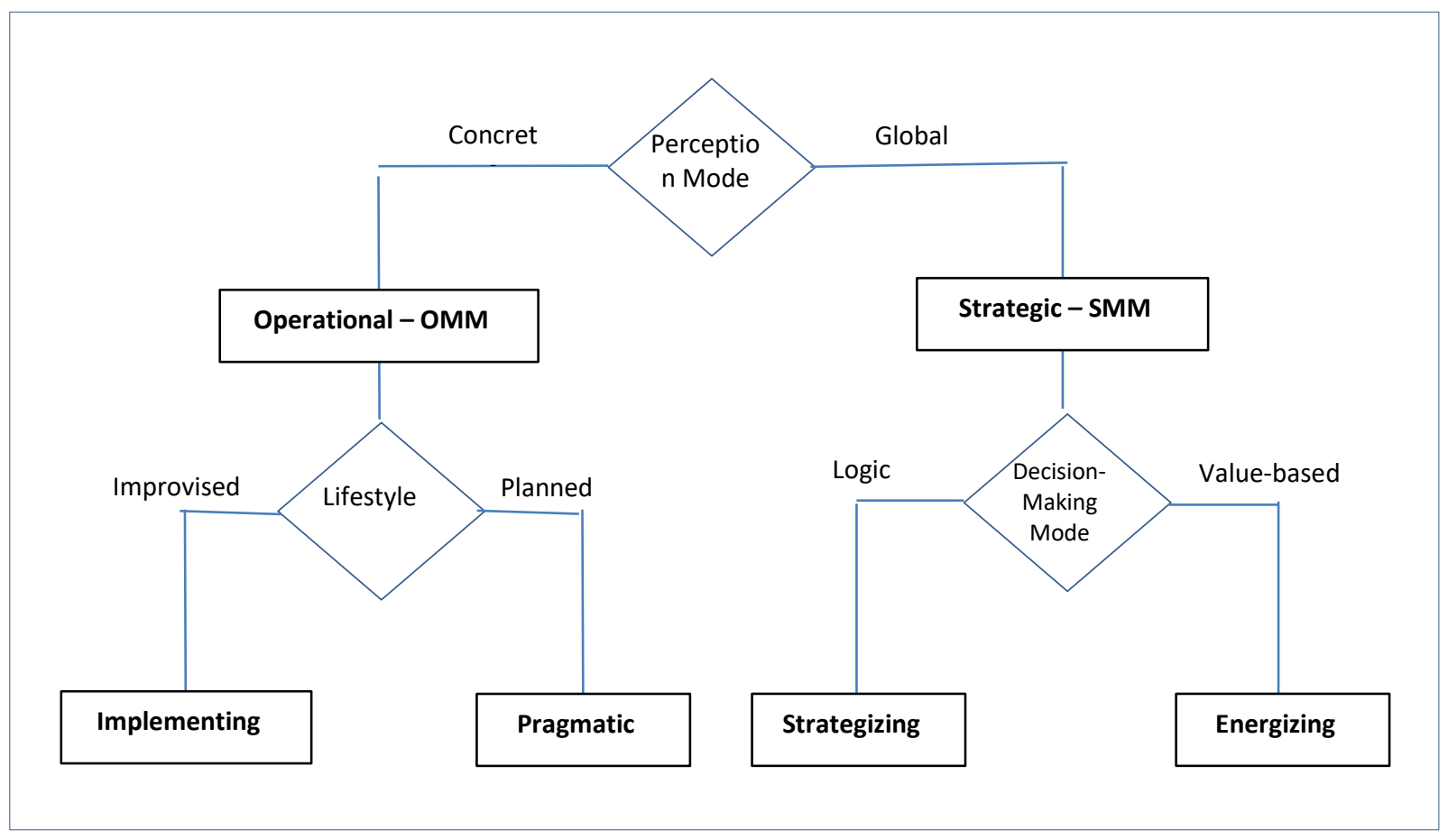

Figure 1. Diagram for classifying the respondents into the mental models

Source: prepared based on Keirsey and Bates (1984), Kroeger and Thuessen (1992) and Silva (1992).

\section{Method}

This study may be characterized as an exploratory research. The following methods were used to collect data: a) the personal inclination questionnaire (PIQ), to define the mental models (Silva, 1992); b) the model adapted from Keller and Weibler (2014), for the study of ambidexterity; and, c) the proposals of Acedo and Galán (2011), to address internationalization incentives.

\subsection{Personal inclination questionnaire (PIQ)}

In the study by Silva (1992), based on a simple random sample, the author reports that the $\mathrm{PIQ}$ showed a high level of content validity and adherence to the studied population in qualitative and quantitative tests. It consists of 26 variables: 5 for the analysis of attitudes - introversion and extraversion; 7 to evaluate the perception mode; 7 to evaluate the decision mode - logical and based on values; and 7 to assess lifestyle - planned and improvised. The respondents indicated their preference on a 7-point scale, comparing the alternatives for each of the variables of the respective factors.

\subsection{Ambidexterity Questionnaire}

It was decided to use the questionnaire developed by Keller and Weibler (2011; 2014), with a focus on the individual level, validated in an exploratory factor analysis and composed of 8 exploration and exploitation variables. The variables had eigenvalues greater than three and explained $58 \%$ of the variance. The exploitation variables measure the willingness to engage in routine tasks that can be performed on a clearly defined schedule $(\alpha=0.85)$.

The exploration variables measure the willingness to engage in new areas of knowledge, in new, complex and unusual tasks, the consequences of which are unknown $(\alpha=0.82)$. A 5-point Likert scale 
was used to evaluate the level of preference for each variable.

\subsection{Stimuli triggering the decision to internationalize}

In order to decide on internationalization issues, entrepreneurs often need support and encouragement, which act as influencers or motivators in this decision. These stimuli can be proactive, associated with a process of deliberate search for internationalization opportunities, or reactive, associated with reactions to changes in the business environment (Acedo \& Galán, 2011; Freeman, Hutchings \& Chetty, 2012). Considering the relationship between the nature of the stimuli and the entrepreneurs' psychological characteristics their perception process, how they organize what has been perceived, decision-making, and their way of interacting with the business environment -, it is possible to associate the stimuli with MMs.

Internationalizing involves a strategic decision. It is a way to optimize internal processes, productivity, and the exploration of new markets (Vahlne \& Jonsson, 2017), which requires willingness to adapt to the complex and changing business environment, and to explore new domains of knowledge, new strengths, new products and new markets, while optimizing the use of their skills (March, 1991; Keller \& Weibler, 2012; Engelman \& Fracasso, 2013 ; Kiss, Williams \& Houghton, 2013).

There are several reasons leading companies adopt internationalization practices (Andersson, 2000) (Chart 3). In general, as they gain international experience and knowledge (Eriksson, Johanson \& Majkgård, 2015), companies expand their business to more distant markets, in a gradual and evolutionary process (Oliveira; Figueira \& Pinhanez, 2018), preferring to work in markets that are similar to those of their country of origin (Khojastehpour \& Johns, 2014; Loué, 2018).

Internationalizing can make companies more competitive, larger, and earn higher revenues; moreover, due to the higher productivity, they may acquire greater resilience to recession.

Chart 3. Reasons for internationalization

\begin{tabular}{|l|l|}
\hline REASONS FOR INTERNATIONALIZATION & \multicolumn{1}{|c|}{ REFERENCES } \\
\hline Company's growth and survival & $\begin{array}{l}\text { González \& Cabanelas (2000), Andersson (2000), } \\
\text { Souza } \text { et al. (2012). }\end{array}$ \\
\hline Market saturation & $\begin{array}{l}\text { Wood \& McCarthy (2014), Ramirez-Hurtado } \text { et } \\
\text { al. (2018). }\end{array}$ \\
\hline Low population growth & $\begin{array}{l}\text { Sato \& Yamamoto (2005; 2008), Ferreira et al. } \\
\text { (2011). }\end{array}$ \\
\hline Extending the product's life cycle & $\begin{array}{l}\text { da Silva, Chagas \& Siqueira (2012), Souza, } \\
\text { Vasconcellos \& Corrêa, (2012), Francischini, } \\
\text { Furtado \& Garcia (2015). }\end{array}$ \\
\hline Possibilities offered by new markets & $\begin{array}{l}\text { Östlin, Sundin \& Björkman (2009), Jovanov \& } \\
\text { Stojanovski (2012). }\end{array}$ \\
\hline Less competition than the market of origin & $\begin{array}{l}\text { Bacon \& Butler (2007); Antunes, \& Martins, } \\
\text { (2013). }\end{array}$ \\
\hline Access to technology, resources and capabilities & $\begin{array}{l}\text { Ferreira et al. (2011), Levy, Mota \& Wermelinger } \\
\text { (2010), Dias, Caputo \& Marques (2012). }\end{array}$ \\
\hline $\begin{array}{l}\text { Diversification of the investment risk } \\
\text { Response to stimuli and/or incentives from the } \\
\text { country of origin and/or destination }\end{array}$ & $\begin{array}{l}\text { Acedo \& Galán (2011), Schellenberg, Harker \& } \\
\text { Jafari (2018). }\end{array}$ \\
\hline
\end{tabular}

Source: prepared by the authors.

For this survey, the model proposed by Acedo and Galán (2011) was used, based on Lautanen (2000): proactive or reactive. The stimuli were evaluated by 12 judges, participants in the Professional Master's Program in Entrepreneurship at FEA/USP, all with professional experience in the field of business, who classified them as proactive - related to the deliberate search for internationalization opportunities - or reactive - related to a more passive attitude of reaction to changes in the 
business environment. Variables with an agreement index above $75 \%$ were accepted, including: 7 exploration variables and 7 exploitation variables. The respondents were asked to point out as many triggering factors as they deemed appropriate.

The variables were grouped in a questionnaire, which was applied to a convenience sample at two universities: Universidade Estadual de Campinas (UNICAMP), from Brazil, and Universitat Politècnica de Catalunya (UPC), from Spain. In both countries, questionnaires were applied in local languages. The context of economic crisis - especially considering the unemployment crisis - that characterizes these countries (since 2009 in Spain and since 2014 in Brazil) creates a common substrate that justifies the decision to choose these countries for the purposes of the proposed analysis.

\subsection{Sample}

The choice of higher education students to compose the sample is justified by the fact that many studies target this population's willingness and intention to become entrepreneurs (Palalić et al., 2017; Oliver \& Jorre de St Jorre, 2018). The convenience sample consisted of 285 business school students with a similar academic profile: 135 from UNICAMP (47.37\%) and 150 from UPC (52.63\%), between 19 and 25 years of age.

As these universities offer basic training in entrepreneurship, they are familiar with the topic, and their academic choice (Business School) brings them closer to it. Due to the employment conditions of both countries, the respondents, when starting their professional life, will be faced with a career choice, and will probably consider entrepreneurship as a potential option, a frequent phenomenon among university students (Holienka, Gal \& Kovačičová, 2017). These similarities reinforce the suitability of the convenience sample chosen for the proposed analysis.

In Brazil, the questionnaire, applied in person in the classroom, was answered by 135 students. In Spain, the questionnaire was answered in two different ways (150 students): the first online (Google Forms), by 80 students; the second in person, by 70 students. The former were invited to attend the inperson applications, and the questionnaire was answered by those who were willing to participate. To obtain the online answers, e-mails were sent to the students of the program, requesting their collaboration and indicating the link to the questionnaire. The demographic data attested the similarity of the participants' social and academic profile, a necessary requirement to establish a parallel between the two countries, indicating a low level of influence on the factors involved. Data collection took place between May and August 2017.

\subsection{Method of data analysis}

A formula was developed to analyze the answers and compare the 5 indexes created (ambidexterity; mental models (3); and proactivity/reactivity), adapted from the original authors to standardize and resize the values of the instruments, due to differences between the scales of the mental models and ambidexterity.

In the case of the proactivity/reactivity index, it is answered with Yes/No answers (and not on a Likert scale). Thus, instead of using the original formulas

$$
\begin{aligned}
& \text { Ambidexterity Index }=\frac{\sum \mathrm{Xi}_{\mathrm{X}}}{\sum \mathrm{Y}_{\mathrm{T}} / \mathrm{Y}_{\mathrm{T}}} \\
& \text { Proactivity Index }=\mathrm{p} / \mathrm{p}_{\mathrm{T}}-\mathrm{r} / \mathrm{r}_{\mathrm{T}}
\end{aligned}
$$

The following formula was developed,

$$
\text { Index [indicator }]=\frac{\left(\sum_{i=1}^{n} X_{i}\right)-\left(\sum_{i=1}^{n} Y_{i}\right)}{\left(\sum_{i=1}^{n} X_{\max , i}\right)-\left(\sum_{i=1}^{n} Y_{\max , i}\right)}+0.5
$$


Where:

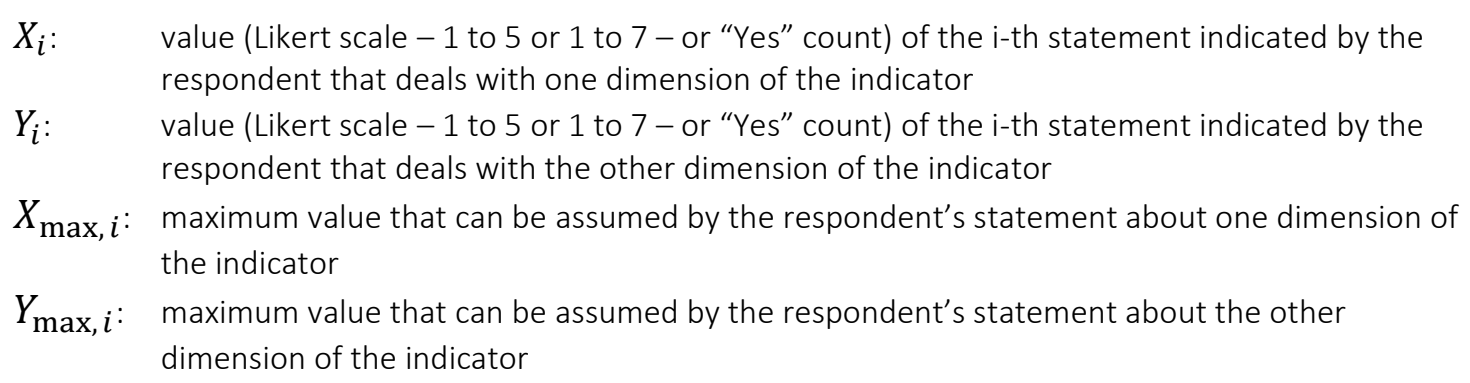

Thus, we have the following conditions for each index, as shown in Chart 4.

Chart 4. Summary of the study's indexes

\begin{tabular}{|l|l|c|c|l|}
\hline \multicolumn{1}{|c|}{ Indicator } & \multicolumn{1}{|c|}{ Dimension ${ }^{1}$} & Code Index & Scale & In the event of a tie $^{2}$ \\
\hline Ambidexterity & $\begin{array}{l}\text { ExploRer } \\
\text { ExploiTer }\end{array}$ & R_T & & Explorer \\
\cline { 2 - 3 } Mental Perception Model & $\begin{array}{l}\text { Global } \\
\text { Concrete }\end{array}$ & G_C & Global \\
\cline { 2 - 3 } Mental Decision-Making Model & $\begin{array}{l}\text { Value-based } \\
\text { Logical }\end{array}$ & V_L & {$[0,1]$} & Value-based \\
\hline Mental Lifestyle Model & $\begin{array}{l}\text { Improvised } \\
\text { Planned }\end{array}$ & I_P & Improvised \\
\hline Proactivity/Reactivity & $\begin{array}{l}\text { Proactive } \\
\text { Reactive }\end{array}$ & P_R & Undefined ${ }^{2}$ \\
\hline
\end{tabular}

Source: prepared by the authors.

Notes: ${ }^{1}$ A tie means an index $=0.5$.

Notes: ${ }^{2}$ The uppercase and bold letters form the index's acronym, and its order indicates the preference (classification) of the respondent, considering: Index $>0.5=1$ st dimension of the indicator; Index $<0.5=2$ nd dimension of the indicator.

Notes: ${ }^{3}$ In the case of the Proactivity/Reactivity Indicator $\left(P_{-} R\right)$, if there is a tie $\left(P_{-} R=0.5\right)$, a 3rd classification called "Undefined" is created.

For the five indexes obtained, values greater than 0.5 indicate preference for the style related to the first dimension listed in Table 1, which is also noted in the order of the letters forming the Index Code. Similarly, values lower than 0.5 show that the respondent has preference for a style related to the second dimension listed in Table 1. Thus, a hypothetical value of 0.68 for Ambidexterity $\left(R_{-} T\right)$ shows preference for ExploRation. In case the indexes are equal to 0.5 , the tie was broken according to criteria from the literature (Briggs \& Myers, 1995; Tieger \& Baron-Tieger, 1998; Pearman et al., 2006). As no indicative references were found for the adoption of a similar criterion for the Proactivity/Reactivity Index, a 3rd classification was created: "Undefined". To classify the respondents into the two MMs and their subtypes, a heuristic was developed based on Briggs \& Myers (1995), Tieger \& Baron-Tieger (1998) and Pearman et al. (2006). 
Table 1. Classification of the respondents according to the measured indexes

\begin{tabular}{|c|c|c|c|c|c|c|}
\hline \multicolumn{2}{|c|}{ Indicator/Dimension } & Scale & Total & Brazil & Spain & $\begin{array}{c}\chi 2 \\
\text { (Significance)2 }\end{array}$ \\
\hline \multicolumn{2}{|l|}{ Sample size } & $n$ & 285 & 135 & 150 & \\
\hline \multicolumn{7}{|l|}{ Ambidexterity } \\
\hline \multicolumn{2}{|l|}{ ExploRer } & $\%$ & 50.5 & 39.3 & 60.7 & \multirow{2}{*}{$13.026^{* * *}$} \\
\hline \multicolumn{2}{|l|}{ ExploiTer } & $\%$ & 49.5 & 60.7 & 39.3 & \\
\hline \multicolumn{7}{|l|}{ Mental model } \\
\hline \multirow[t]{2}{*}{ Perception } & Concrete & $\%$ & 67.7 & 72.6 & 63.3 & \multirow{2}{*}{$2.787^{+}$} \\
\hline & Global & $\%$ & 32.3 & 27.4 & 36.7 & \\
\hline \multirow{2}{*}{$\begin{array}{r}\text { Decision } \\
\text { Making }\end{array}$} & Value-based & $\%$ & 39.6 & 34.8 & 44.0 & \multirow{2}{*}{$2.505^{+}$} \\
\hline & Logical & $\%$ & 60.4 & 65.2 & 56.0 & \\
\hline \multirow{2}{*}{ Lifestyle } & Improvised & $\%$ & 68.1 & 77.8 & 59.3 & \multirow{2}{*}{$11.121^{* * *}$} \\
\hline & Planned & $\%$ & 31.9 & 22.2 & 40.7 & \\
\hline \multicolumn{2}{|c|}{ Proactivity/Reactivity $^{1}$} & $n$ & 232 & 82 & 150 & \\
\hline & Proactive & $\%$ & 62.9 & 72.0 & 58.0 & \multirow{3}{*}{$4.843^{+}$} \\
\hline & Reactive & $\%$ & 20.3 & 17.1 & 22.0 & \\
\hline & Undefined & $\%$ & 16.8 & 11.0 & 20.0 & \\
\hline \multicolumn{2}{|l|}{ Strategic style } & $n$ & 285 & 135 & 150 & \\
\hline \multicolumn{2}{|l|}{ Strategic } & $\%$ & 32.3 & 27.4 & 36.7 & \multirow{2}{*}{$2.787^{+}$} \\
\hline \multicolumn{2}{|l|}{ Operational } & $\%$ & 67.7 & 72.6 & 63.3 & \\
\hline \multirow{2}{*}{ Strategic } & Strategizing & $\%$ & 21.1 & 17.8 & 24.0 & \multirow{4}{*}{$10.156^{*}$} \\
\hline & Energizing & $\%$ & 11.2 & 9.6 & 12.7 & \\
\hline \multirow{2}{*}{ Operational } & Pragmatic & $\%$ & 52.6 & 62.2 & 44.0 & \\
\hline & Implementing & $\%$ & 15.1 & 10.4 & 19.3 & \\
\hline
\end{tabular}

Source: Prepared by the authors.

Note 1: 53 Brazilian respondents did not answer these statements.

Note 2: Non-parametric Chi-square test. Significance: $\mathrm{p}<0.05=*, \mathrm{p}<0.01=* *, \mathrm{p}<0.001=* * *$, not significant $=^{+}$.

The first step was to verify the Perception Mode Index: concrete (Operational) or global (Strategic). If concrete, the relevant index to be used in the next step will be the lifestyle index - planned or improvised -, which will result in the implementing and pragmatic mental models, respectively. If global, the next step will be to verify the decision-making mode - logical or based on values - which will result in the strategizing and energizing mental models.

\section{Results and Discussion}

Among the results, the following stand out: Spaniards have (1) greater preference for the global perception mode (36.7\%) than Brazilians (significance $=p<0.05) ;(2)$ greater preference for values $(44.0 \%)$ than Brazilians (34.8\%) (significance $=p<0.05$ ); and (3) greater preference for a planned lifestyle $(40.7 \%)$ than Brazilians (22.2\%) (significance $=p<0.001$ ). These results are consistent with the MMs defined: Spaniards have higher preference for the SMM
(36.7\%) than Brazilians (27.4\%) (significance = $\mathrm{p}<0.05)$. The significance indexes make it possible to indicate the effect of the country of origin on the MM. Despite these significant differences, Brazilians and Spaniards showed a tendency towards the OMM, which was greater for Brazilians (72.6\%) than for Spaniards (63.3\%). Based on the analysis of the mental models, it is possible to state that there was a statistically significant difference in all measured indexes. (Table 1).

Regarding ambidexterity, the data indicate $(p<0.001)$ that Spaniards tend to have greater preference for exploration (60.7\%) than Brazilians (39.3\%) (Table 1). As for the proactivity index, the results indicate greater willingness for proactivity among Brazilians (72.6\%) compared to Spaniards (58.0\%), and lower incidence of the "undefined" category among Brazilians (11.08\%) compared to Spaniards (20.0\%) $($ significance $=p<0.05)$. 
The results show that there is influence of the country of origin on the $\mathrm{MM}$, on the strategic decision-making process, and on ambidexterity.

The Anova statistical technique was employed to perform an analysis using the mean value calculated for each index. This is justified since the mean values obtained on a Likert scale are accepted as being on a ratio scale and, therefore, preserve much more information than when on a nominal scale. However, considering the case of two respondents, one with a mean value of 0.51 for ambidexterity and the other with a mean value of 0.49 : the former would be classified as an "explorer", and the second as an "exploiter", but with minimal difference between scores $(0.51-0.49=0.02)$, practically irrelevant from a practical point of view.

According to the literature, the main assumptions of Anova are homogeneity in the variance of errors in the sample observations and their normality. The
Shapiro-Wilk test and the Levene test were used to ensure normality and equality between variances, respectively (Table 2). When identifying the heterogeneity of variances, the Anova Welch technique was used to compare the means. Although Anova is effective against inconsistencies in the hypothesis of normality, Kruskal-Wallis nonparametric tests were performed to confirm the results obtained.

As can be seen in Table 2, only the MM decision index ( $V_{-} L$ ) has no homoscedasticity, and, therefore, for this index, the value shown in Table 2 is the one obtained with Anova Welch. Regarding the normality test, as two of the main tests (Kolmogorov-Smirnov and Shapiro-Wilk) do not converge in four of the five indexes (only for P_R - both tests show that the distribution is not normal), it was decided to perform the Kruskal-Wallis non-parametric test to verify the differences in the means of all five indexes (Table 2).

Table 2. Results of the normality and homogeneity tests and indication of statistical tests to be applied

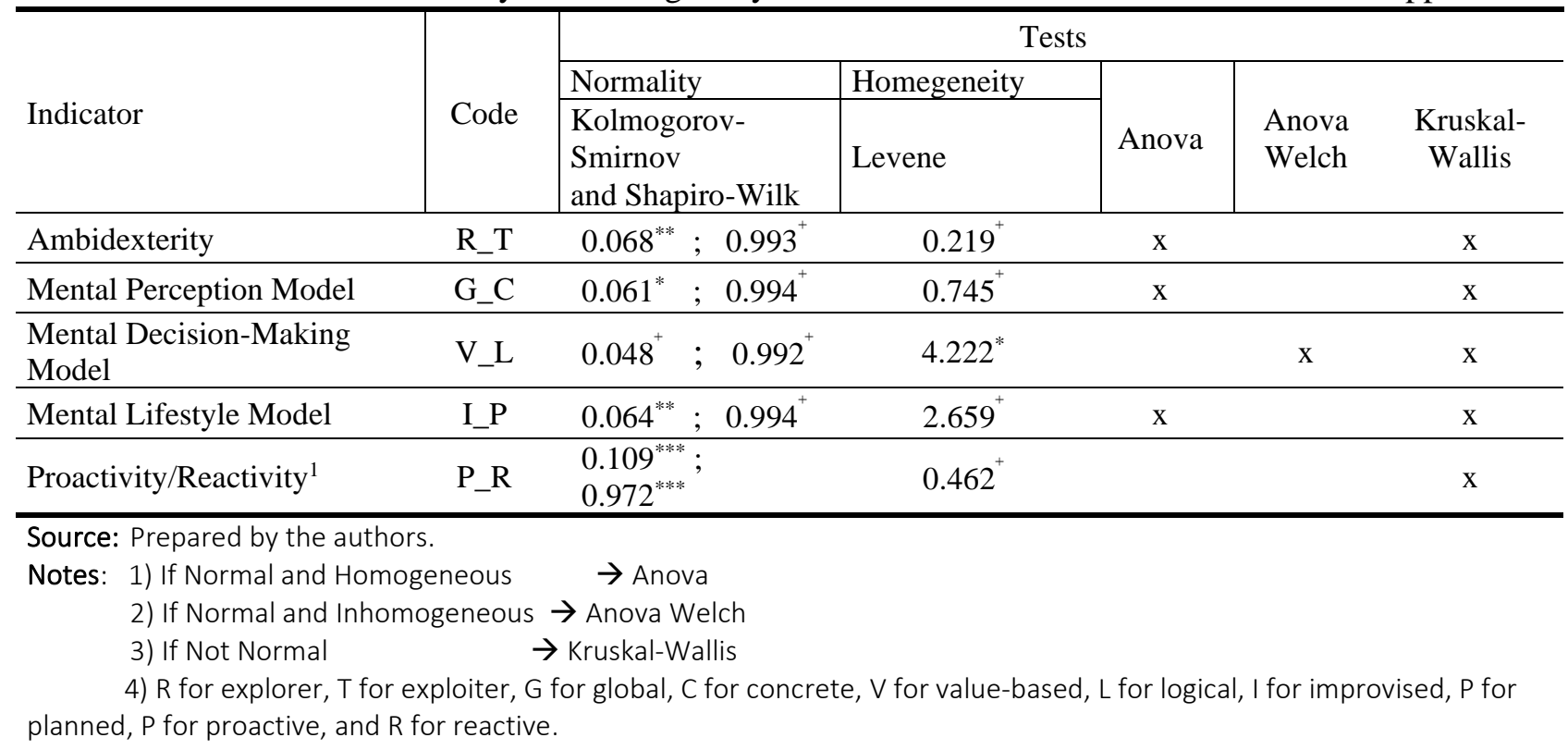


Table 3. Mean value of the indexes and their significance tests

\begin{tabular}{l|cc|c|c|c|c}
\hline \multirow{2}{*}{ Index $^{1}$} & \multirow{2}{*}{ Code } & \multirow{2}{*}{ General } & \multicolumn{2}{|c|}{ Nationality } & \multicolumn{2}{|c}{ Significance $^{2,3}$} \\
\cline { 4 - 8 } & & & Brazil & Spain & Anova or (Anova Welch) & $\begin{array}{c}\text { Kruskal- } \\
\text { Wallis }\end{array}$ \\
\hline Ambidexterity & R_T & 0.49 & 0.46 & 0.52 & $17.545^{* * *}$ & $21.994^{* * *}$ \\
\hline Perception Mode & G_C & 0.43 & 0.41 & 0.45 & $6.587^{*}$ & $6.144^{*}$ \\
\hline Decision-Making Mode & V_L & 0.54 & 0.57 & 0.51 & $\left(10.926^{* *}\right)$ & $10.888^{* *}$ \\
\hline Lifestyle & I_P & 0.56 & 0.60 & 0.52 & $19.668^{* * *}$ & $21.036^{* * *}$ \\
\hline Proactivity/Reactivity & P_R & 0.59 & 0.62 & 0.58 & & $4.288^{*}$ \\
\hline
\end{tabular}

Source: Prepared by the authors.

Notes: 1) All indexes vary between 0 and 1.

2) If Normal and Homogeneous $\rightarrow$ Anova

If Normal and Inhomogeneous $\rightarrow$ Anova Welch

If Not Normal $\rightarrow$ Kruskal-Wallis

3) Significance: $\mathrm{p}<0.05=*, \mathrm{p}<0.01=* *, \mathrm{p}<0.001=* * *$, not significant $=^{+}$.

4) $\mathrm{R}$ for explorer, $\mathrm{T}$ for exploiter, $\mathrm{G}$ for global, $\mathrm{C}$ for concrete, $\mathrm{V}$ for value-based, $\mathrm{L}$ for logical, I for improvised, $\mathrm{P}$ for planned, $\mathrm{P}$ for proactive, and $\mathrm{R}$ for reactive.

Table 3 presents the mean values of the indexes and their significance tests (Anova Welch and KruskalWallis). The results indicate that Spaniards have a more pronounced attitude towards exploration (0.52) than Brazilians (0.46) (significance $p<0.001$ ). The results for decision-making mode show that Spaniards have greater preference for the logical mode (0.45) than Brazilians (0.41) (significance $\mathrm{p}<0.05)$. Regarding lifestyle, Brazilians show greater preference for improvisation (0.60) compared to Spaniards (0.52) (significance $p<0.001$ ). As for the willingness to respond to stimuli, Brazilians tend to be more proactive (0.62) than Spaniards (0.58) (significance $\quad \mathrm{p}<0.001 /$ Kruskal-Wallis). These differences make it possible to state that, for this sample, the country of origin has a significant influence on these factors.

The literature on the relationship between ambidexterity and MMs allows hypothesizing that there is correlation between exploration and the SMM, and between exploitation and the OMM, which was verified by performing a cross-correlation analysis. The results (Table 4) indicate the relationship of SMMs with exploration (63.0\%) and exploitation (37.0\%), and the relationship of OMMs with exploration (55\%) and exploration (45\%), corroborating the study by Acedo and Galán (2011).

Table 4. Correlation between Mental Models and Ambidexterity

\begin{tabular}{l|l|c|c|c|c|c}
\hline \multicolumn{2}{l}{ Indicator/Dimension } & \multirow{2}{*}{ Scale } & \multirow{2}{*}{ Total } & \multicolumn{2}{|c}{ Mental Model } & \multirow{2}{*}{$\chi 2^{\text {(Significance)2 }}$} \\
\cline { 5 - 6 } & & & Strategic & Operational & \\
\hline \multirow{2}{*}{ Sample size } & & $n$ & 285 & $92(100)$ & $\begin{array}{c}193 \\
(100)\end{array}$ & \\
\hline \multirow{2}{*}{ Ambidexterity } & ExploRer & $n(\%)$ & & $58(63)$ & $86(45)$ & \multirow{2}{*}{$8.515^{* *}$} \\
\cline { 3 - 6 } & ExploiTer & $n(\%)$ & & $34(37)$ & $107(55)$ & \\
\hline
\end{tabular}

Source: : Prepared by the authors.

Note 1: 53 Brazilian respondents did not answer these statements.

Note 2: Non-parametric Chi-square test. Significance: $p<0.05=*, p<0.01=* *, p<0.001=* * *$, not significant $=^{+}$.

\section{Final remarks}

Considering the relationship found between mental models, ambidexterity and the reaction to internationalization stimuli, it is possible to conclude that entrepreneurs with the SMM and preference for exploration will tend to have a more proactive behavior in relation to internationalization. This reinforces the importance and need for training and guidance to enable entrepreneurs to identify and proactively respond to internationalization opportunities. Likewise, considering the greater incidence of the OMM in relation to the SMM, the 
results found may indicate the convenience and effectiveness of investing in the SMM's development to increase the willingness to engage in exploratory activities, which could increase the willingness to internationalize.

In this way, it is possible to expect that entrepreneurs with the personal characteristics indicated by the strategic mental model will tend to have greater probability of success in their internationalization initiatives. The results reinforce the importance and need for training and guidance so that entrepreneurs, when developing their strategic mental model and a positive attitude toward exploration, not only optimize their businesses, but also identify and proactively respond to internationalization opportunities, thus perceiving globalization as one of them.

The study also revealed the effect of the country of origin on the indexes found. Brazilians have greater operational tendency, i.e., predominance of the OMM; a decision-making process based more on logic than on values; and greater preference for an improvised than for a planned lifestyle. They also revealed greater preference for exploitation, showing less possibility of engaging in internationalization based on proactive stimuli, which is different from the results obtained for Spaniards, whose tendency was found to be more strategic (SMM) than operational (OMM), and who also showed preference for a more improvised lifestyle. The Spaniards also showed a more pronounced preference for exploration than the Brazilians, suggesting greater possibility of engaging in an internationalization process.

The present study may be used to understand the effects of triggering stimuli and their relationship with the students' personal characteristics, based on the definition of these students' mental models and their preferences in relation to ambidexterity. It also contributes to the agencies in charge of creating programs to encourage internationalization, given that the results indicate that these programs' longterm effectiveness may be increased by better adapting them to the preferences and characteristics of entrepreneurs. This may lead to the development of more favorable attitudes on the part of entrepreneurs in relation to operations in foreign markets. A limitation of this study is having used samples from only two countries. Future studies may use larger samples and contribute to the discussion of the results.

Considering the initial relationship found between mental models and attitudes towards ambidexterity, it is recommended that research is carried out to verify whether, based on a representative sample, this relationship is consistent, which would reinforce the convenience and effectiveness of investing in the SMM's development as a way of increasing the willingness of entrepreneurs to engage in exploratory activities and, consequently, in internationalization.

\section{References}

Acedo, F. J., \& Galán, J. L. (2011). Export stimuli revisited. International Small Business Journal, 29(6), 648-670.

Ahmed, A., Hasnain, N., \& Venkatesan, M. (2012). Decision making in relation to personality types and cognitive styles of business students. IUP Journal of Management Research, 11(2).).

Além, A. C., \& Cavalcanti, C. E. D. S. (2005). BNDES e o apoio à internacionalização das empresas brasileiras: Algumas Reflexões.

Andersson, S. (2000). The internationalization of the firm from an entrepreneurial perspective. International studies of management \& organization, 30(1), 63-92.

Antunes, I. C. M., \& Martins, F. V. (2013). O impacto da distância entre países na estratégia de marketing internacional. International Journal of Marketing, Communication and New Media, 1(1).

Bachert, M. C., A., Wechsler, S., \& de Lara Machado, W. (2016). Construção e validação do Inventário de Estilos de Temperamento do Professor. Psico, 47(1), 56-67.

Bacon, F. R., \& Butler, T. W. (1998). Achieving planned innovation. Simon and Schuster.

Bandeira-de-Mello, R., Fleury, M. T. L., Aveline, C. E. S., \& Gama, M. A. B. (2016). Unpacking the ambidexterity implementation process in the internationalization of emerging market multinationals. Journal of Business Research, 69(6), 2005-2017. 
Birkinshaw, J., \& Gupta, K. (2013). Clarifying the distinctive contribution of ambidexterity to the field of organization studies. Academy of Management Perspectives, 27(4), 287-298.

Brasil. (2016). Como exportar: Espanha. Ministério das Relações Exteriores. Divisão de Inteligência Comercial, Brasília: MRE,

Bressan, F. (2018). The Executive's Personal Characteristics Influences on the Strategic DecisionMaking Process. In Closing the Gap Between Practice and Research in Industrial Engineering (pp. 19-28). Springer, Cham.

Bressan, F.; Spagnol, G. S.; Min, L. L. (2015). Understanding differences in learning process. Journal of Epilepsy and Clinical Neurophysiology, v. 4, p. 63 ,

Bressan, F.; Toledo, G.L. (2013) A Influência das características pessoas do empreendedor nas escolhas estratégicas e no processo de tomada de decisão. Revista Psicologia: Organização e Trabalho, v. 13, n. 3, pp. 309-324.

Briggs-Myers, I., \& Myers, P. B. (1995). Gifts differing. Mountain View, CA: Davies-Black Publishing

Carrington, D. J., Combe, I. A., \& Mumford, M. D. (2019). Cognitive shifts within leader and follower teams. The Leadership Quarterly, 30(3), 335-350.

da Silva, I. M., das Chagas, A. C. C., \& Siqueira, S. V. (2012). Características de empreendedorismo internacional no processo de internacionalização. Revista Eletrônica de Negócios Internacionais (Internext), 7(2), 107-136.

Daniel, P. A., \& Daniel, C. (2018). Complexity, uncertainty and mental models, International journal of project management, 36(1), 184-197.

Dias, A. C. A., Caputo, A. C., \& Marques, P. H. D. M. (2012). Motivações e impactos da internacionalização de empresas. Disponível em https://web.bndes.gov.br/bib/jspui/handle/1408/25

74, acesso 31/06/2019

Engelman, R., \& Fracasso, E. M. (2013). Contribuição das incubadoras tecnológicas na internacionalização das empresas incubadas. Revista de Administração, 48(1), 165-178.
Eriksson, K., Johanson, J., Majkgård, A., \& Sharma, D. D. (2015). Experiential knowledge and cost in the internationalization process. In Knowledge, Networks and Power (pp. 41-63). Palgrave Macmillan, London.

Felder, R. M., Felder, G. N., \& Dietz, E. J. (2002). The effects of personality type on engineering student performance and attitudes. Journal of engineering education, 91(1), 3-17.

Ferreira, M. P.; Serra, F. (2008). Foreign entry modes under institutional pressures. Revista de Ciências da Administração, v. 10, n. 22, p. 11-29.

Feuerstein, R., Falik, L., \& Feuerstein, R. S. (2015). Changing minds and brains. Teachers College Press.

Francischini, A. S. N., Furtado, J., \& Garcia, R. (2015). Tecnologia e trajetórias de internacionalização precoce. Gest. Prod., São Carlos, 22(2), 267-279.

Freeman, S., Hutchings, K., \& Chetty, S. (2012). Born-globals and culturally proximate markets. Management International Review, 52(3), 425-460.

George, G., Wiklund, J., \& Zahra, S. A. (2005). Ownership and the internationalization of small firms. Journal of management, 31(2), 210-233.

González, J., \& Cabanelas, J. (2000). La internacionalización de la pequeña y mediana empresa gallega. Consorcio Zona Franca de Vigo Estudios. Disponível em http://datos.bne.es/edicion/bimo0001653412.html. Acesso em: 20/11/2017.

Harrington, R., \& Loffredo, D. A. (2010). MBTI personality type and other factors that relate to preference for online versus face-to-face instruction. The Internet and Higher Education, 13(1-2), 89-95.

Holienka, M., Gal, P., \& Kovačičová, Z. (2017). Drivers of student entrepreneurship in Visegrad four countries. Central European Business Review, 6(2), 54.

Jovanov, T., \& Stojanovski, M. (2012). Marketing knowledge and strategy for SMEs. Thematic Collection of papers of international significance:" Reengineering and entrepreneurship under the 
contemporary conditions of enterprise business", 131-143.

Jung, C. (2016). Psychological types. Routledge.

Keirsey, D., \& Bates, M. M. (1984). Please understand me. Del Mar, CA: Prometheus Nemesis.

Keller, T., \& Weibler, J. (2014). Behind Managers' Ambidexterity. Schmalenbach Business Review, 66(3), 309-333.

Khauaja, D. M. R., \& Toledo, G. L. (2012). O processo de internacionalização de empresas brasileiras. Internext, 6(1), 42-62.

Khojastehpour, M., \& Johns, R. (2014). Internationalization and relationship marketing. European Business Review, 26(3), 238-253.

Kiss, A. N., Williams, D. W., \& Houghton, S. M. (2013). Risk bias and the link between motivation and new venture post-entry international growth. International Business Review, 22(6), 1068-1078.

Laureiro-Martínez, D., Brusoni, S., Canessa, N., \& Zollo, M. (2015). Understanding the explorationexploitation dilemma: An fMRI study of attention control and decision-making performance. Strategic Management Journal, 36(3), 319-338.

Lautanen, T. (2000). Modelling Small Firms' Decisions to Export-Evidence from Manufacturing Firms in Finland, 1995. Small Business Economics, 14(2), 107-124.

Lee, K. C. (2015). Dynamic resource allocation for exploitation and exploration with ambidexterity. Computers in Human Behavior, 42, 120-126.

Leonidou, L. C., Katsikeas, C. S., Palihawadana, D., \& Spyropoulou, S. (2007). An analytical review of the factors stimulating smaller firms to export. International Marketing Review, 24(6), 735-770.

Levy, B. P., Mota, M. C., \& Wermelinger, M. B. (2010). O uso de networks no processo de internacionalização. Internext, 5(1), 50-83.

López, I., Rodríguez, E., \& Rugitsky, F. (2012). O modelo espanhol. Novos Estudos-CEBRAP, (92), 81102.
Loué, C. (2018). Firms and internationalization. Journal of Small Business \& Entrepreneurship, 1-30.

Luiz, G. V. (2011). Características do temperamento e suas influências no comportamento do consumidor. Revista Brasileira de Marketing, 10(2), 30-53.).

March, J. G. (1991). Exploration and exploitation in organizational learning. Organization science, 2(1), 71-87.

Magzan, M. (2012). Mental models for leadership effectiveness. Journal of engineering management and competitiveness (JEMC), 2(2), 57-63.)

Modak, S., Patel, M. C., Pal, P. K., Das, L., \& Nain, M. S. (2018). A study of entrepreneurial competencies of postgraduate students in agriculture. Indian Journal of Agricultural Sciences, 88(9), 1391-5.

Myers, I. B., \& Myers, P. B. (2010). Gifts differing. Nicholas Brealey.

Neal, G., \& Neal, J. (2009). Assessment of Keirsey Personality Temperaments among Aerospace Electronics Students. International Journal of Professional Aviation Training \& Testing Research, 3(1).

Oliveira, R. H., Figueira, A. R., \& Pinhanez, M. (2018). Uppsala model: A contingent theory to explain the rise of EMNEs. Internext, 13(2).

Oliver, B., \& Jorre de St Jorre, T. (2018). Graduate attributes for 2020 and beyond. Higher Education Research \& Development, 37(4), 821-836.

O'Reilly III, C. A., \& Tushman, M. L. (2013). Organizational ambidexterity: Past, present, and future. Academy of management Perspectives, 27(4), 324-338.

Östlin, J., Sundin, E., \& Björkman, M. (2008). Importance of closed-loop supply chain relationships for product remanufacturing. International Journal of Production Economics, 115(2), 336-348.

Palalić, R., Ramadani, V., Đilović, A., Dizdarević, A., \& Ratten, V. (2017). Entrepreneurial intentions of university students. Journal of Enterprising 
Communities: People and Places in the Global Economy, 11(03), 393-413.

Pearman, R. R., Lombardo, M. M., \& Eicheringer, R. W. (2006). You: Being more effective in your MBTI type. Lominger.

Raisch, S., Birkinshaw, J., Probst, G., \& Tushman, M. L. (2009). Organizational ambidexterity: balancing exploitation and exploration for sustained performance. Organization science, 20(4), 685-695.

Ramirez-Hurtado, J. M., Berbel-Pineda, J. M., \& Palacios-Florencio, B. (2018). Study of the influence of socio-economic factors in the international expansion of Spanish franchisors to Latin American countries. PloS one, 13(1).

Routamaa, V., Brandt, T. \& Uusi-Kakkuri, P. (2016) Personality of Finnish innovative entrepreneurs, Int. J. Entrepreneurship and Small Business, Vol. 29, No. 1, pp.133-148;

Sato, Y., \& Yamamoto, K. (2005). Population concentration, urbanization, and demographic transition. Journal of Urban Economics, 58(1), 45-61.

Schellenberg, M., Harker, M. J., \& Jafari, A. (2018). International market entry mode. Journal of Strategic Marketing, 26(7), 601-627.
Silva, M. D. L. R. D. (1992). Personalidade e escolha profissional. SP: EPU, 1992.

Souza, A. E., Vasconcellos, E. P. G., \& Corrêa, H. L. (2012). O processo de internacionalização de empresas de software. Internext, 7(2), 1-25.

Spagnol, G. S, Campos, B. M., Bressan, F., \& Li. L. M. (2015). Brain activity in different levels of workplace organization applying 5S: an fMRI study using a search-based task paradigm. Journal of Epilepsy and Clinical Neurophysiology, 21, 48-48.

Tieger, P. D., Barron, B., \& Tieger, K. (2014). Do what you are. Little, Brown.

Vahlne, J. E., \& Jonsson, A. (2017). Ambidexterity as a dynamic capability in the globalization of the multinational business enterprise (MBE). International Business Review, 26(1), 57-70.

Wood, S., \& McCarthy, D. (2014). The UK food retail 'race for space' and market saturation. The international review of retail, distribution and consumer research, 24(2), 121-144.

Zahra, S. A., Korri, J. S., \& Yu, J. (2005). Cognition and international entrepreneurship. International Business Review, 14(2), 129-146.

\section{About Authors}

Flávio Bressan - Universidade Estadual de Campinas - Unicamp, Campinas, São Paulo, (Brasil). E-mail: bremat@terra.com.br Orcid id: https://orcid.org/0000-0002-5394-9506

Cristiano Morini - Universidade Estadual de Campinas - Unicamp, Campinas, São Paulo, (Brasil). E-mail: cristiano.morini@fca.unicamp.br Orcid id: https://orcid.org/0000-0003-2868-3280

Edmundo Inácio Júnior - Universidade Estadual de Campinas - Unicamp, Campinas, São Paulo, (Brasil). E-mail: edmundo.inacio@fca.unicamp.br Orcid id: https://orcid.org/0000-0003-0137-0778

Elisabet Garcia Fuentes - Universitat Politècnica de Catalunya, Barcelona, (Espanha). E-mail: elisabet.gafu@gmail.com Orcid id: https://orcid.org/0000-0002-7214-3436 


\title{
DESVENDANDO O PAPEL DA COGNIÇÃO NO PROCESSO DE INTERNACIONALIZAÇÃO
}

\author{
Flávio Bressan, Cristiano Morini, Edmundo Inácio Júnior, Elisabet Garcia Fuentes ${ }^{\Omega}$ \\ Universidade Estadual de Campinas - Unicamp, Campinas, São Paulo (Brasil) \\ ^Universitat Politècnica de Catalunya, Barcelona (Espanha)
}

\section{DETALHES DO ARTIGO}

Histórico do Artigo:

Recebido: 11 de dezembro de 2018

Aceito: 20 de janeiro de 2020

Disponível online: 01 de maio de 2020

Sistema de revisão "Double blind review"

Editor Científico

Ilan Avrichir

\section{Palavras-chave:}

Ambidestria Gerencial

Modelo Mental

Internacionalização

\section{RESUMO}

Objetivo: O objetivo deste trabalho é analisar a ambidestria gerencial e os modelos mentais nos estímulos disparadores na disposição para a internacionalização. Além disso, verificar se o país de origem provoca diferenças em termos de modelos de cognição.

Método: A coleta de dados consistiu na aplicação de questionário a uma amostra de 285 estudantes dos cursos de Administração e Negócios, do Brasil e Espanha. A heterogeneidade das variâncias foi verificada com a Anova Welch. Para avaliar a normalidade, os testes Kolmogorov-Smirnov e Shapiro-Wilk, e, para confirmação, os testes não paramétricos de Kruskal-Wallis.

Principais resultados: os resultados evidenciaram que o modelo mental estratégico estimula a internacionalização. Na amostra estudada, foi possível verificar que os brasileiros apresentam tendência operacional, com estilo de vida improvisado. Os resultados também são úteis para aprimorar programas de estímulo à internacionalização, considerando os aspectos cognitivos.

Relevância/originalidade: Como originalidade, apresenta-se a criação de índices para a extração de dados sobre o modelo mental e ambidestria, em relação à identificação de fatores pessoais motivadores para a internacionalização.

Contribuições teóricas/metodológicas: A proposição de fórmula para padronizar e reescalar os valores dos instrumentos, devido às diferenças entre as escalas, pode contribuir para incluir uma dimensão pouco estudada em programas de internacionalização: a análise da cognição. 


\title{
DESARROLLANDO EL PAPEL DE LA COGNICIÓN EN EL PROCESO DE INTERNACIONALIZACIÓN
}

\author{
Flávio Bressan, Cristiano Morini, Edmundo Inácio Júnior, Elisabet Garcia Fuentes ${ }^{\Omega}$ \\ Universidade Estadual de Campinas - Unicamp, Campinas, São Paulo (Brasil) \\ ¿Universitat Politècnica de Catalunya, Barcelona (Espanha)
}

\begin{tabular}{l}
\hline \multicolumn{1}{c}{ HISTORIA DEL ARTÍCULO } \\
\hline Historia del Artículo: \\
Recibido: 11 de Diciembre de 2018 \\
Aceptado: 20 de Enero de 2020 \\
Disponible en línea: 01 de Mayo 2020 \\
Double Blind Review System \\
Editor Científico \\
llan Avrichir \\
Palabras-clave: \\
Ambidestreza \\
Modelo mental \\
Internacionalización
\end{tabular}

\section{Cite it like this:}

Bressan, F., Morini, C., Inácio Júnior, E., \& Garcia Fuentes, E. (2020). Unraveling the Role of Cognition in the Internationalization Process. Internext, 15(2), 01-17. doi: http://dx.doi.org/10.18568/internext.v15i2.485
Objetivo: El objetivo de este artículo es verificar los efectos de los estímulos desencadenantes en la internacionalización y si la ambidestreza y los modelos mentales (MM) aumentan la predisposición a las exportaciones, así como si el país de origen causa diferencias en términos de cognición.

Método: La recopilación de datos consistió en aplicar un cuestionario a una muestra de 285 estudiantes de programas de Administración en Brasil y España. ANOVA Welsh se usó para verificar la heterogeneidad de las variaciones, las pruebas de Kolmogorov-Smirnov y Shapiro-Wilk se usaron para evaluar la normalidad, y las pruebas no paramétricas de Kruskal-Wallis se usaron para verificar los resultados de las pruebas anteriores.

Resultados principales: Los resultados mostraron que el MM estratégico facilita la internacionalización. En la muestra estudiada, fue posible verificar que los brasileños muestran una tendencia operativa y un estilo de vida improvisado, lo que denota una menor posibilidad de participar en la internacionalización.

Relevancia: Este estudio es relevante para proponer la creación de índices para obtener datos sobre el MM y la ambidestreza con respecto a la identificación de los factores de motivación personal que influyen en la inserción del emprendedor en los mercados internacionales.

Contribuciones teóricas / metodológicas: Propuesta de una fórmula para estandarizar y reescalar el valor de los instrumentos, ya que las diferencias entre escalas pueden contribuir a la inclusión de una dimensión oculta del proceso de internacionalización: el análisis de la cognición. 